\title{
Age decreases quality of life in adolescents with intractable epilepsy
}

\author{
Prastiya Indra Gunawan*, Theresa Laura Limanto*, and Darto Saharso*
}

ABSTRACT

\section{*Division of Neurology,}

Department of Child Health,

Medical School,

Airlangga University,

Dr. Soetomo Hospital,

Surabaya

\section{Correspondence:}

dr Prastiya Indra Gunawan SpA

Division of Pediatric Neurology,

Department of Child Health,

Faculty of Medicine,

Airlangga University

HP: 08113429476

email: prastiya_ig@yahoo.co.id

Univ Med 2015;34:104-11

DOI: 10.18051/UnivMed.2016.v35.104-111 pISSN: 1907-3062 / eISSN: 2407-2230

This open access article is distributed under a Creative Commons Attribution-Non Commercial-Share Alike 4.0 International License

\section{BACKGROUND}

Intractable epilepsy considerably affects both the private and social life of the patient. The objective of this study was to determine the quality of life of intractable epileptic adolescents and its correlated factors.

\section{METHODS}

A cross sectional study was conducted in the Pediatric Neurology outpatient clinic of Dr. Soetomo Hospital. All intractable epileptic adolescents aged between 10 to 16 years were asked to complete a questionnaire on quality of life in epilepsy for adolescents (QOLIE-AD-48). A multiple linear regression was used to analyze the data through SPSS v17.0.

\section{RESULTS}

Thirty one patients with mean age of $12.41 \pm 1.40$ years were enrolled in the study. The mean duration of diagnosed intractable epilepsy was 6.12 \pm 4.30 years. Mean score for impact of epilepsy was $57.11 \pm 24.50$, for memory and concentration $53.54 \pm 26.66$, physical functioning $65.56 \pm$ 23.67 , social stigma $52.23 \pm 17.48$, social support $52.64 \pm 22.69$, behavior at school $57.51 \pm 26.50$, attitude $53.40 \pm 16.70$ and health perception $61.51 \pm 11.30$. Multiple linear regression results showed that quality of life (QOL) was not significantly correlated with duration of epilepsy, sex and nutritional status $(p>0.05)$, but increasing age was significantly decreases quality of life $(\mathrm{p}<0.05)$.

\section{CONCLUSIONS}

Intractable epileptic adolescents have higher scores for physical functioning and health perception, but lower scores for social stigmatization. Social support has extremely low scores. Increasing age decreases quality of life in adolescents with intractable epilepsy.

Keywords: Intractable epileptic adolescents, quality of life 


\section{Semakin tinggi usia remaja menurunkan kualitas hidup pada epilepsi intraktabel}

\section{ABSTRAK}

\section{LATAR BELAKANG}

Epilepsi intraktabel sangat mempengaruhi kehidupan pasien, baik kehidupan pribadi maupun sosialnya. Tujuan penelitian ini adalah untuk menentukan adanya hubungan antara faktor-faktor dan kualitas hidup pasien epilepsi intraktabel remaja.

\section{METODE}

Sebuah penelitian potong lintang dilakukan di poli neurologi anak RS Dr. Soetomo. Semua penderita epilepsi intraktabel remaja berusia 10-16 tahun diminta untuk mengisi kuesioner kualitas hidup epilepsi remaja (quality of life in epilepsy for adolescents/QOLIE-AD-48). Uji regresi linear ganda diguanakan untuk analisis data dengan piranti lunak SPSS versi 17.0.

\section{HASIL}

Tiga puluh satu pasien dengan rata-rata usia 12,41 \pm 1,40 tahun diikut sertakan pada penelitian. Lama terdiagnosis mengalami epilepsi intraktabel rata-rata 6,12 $\pm 4,30$ tahun. Nilai rata-rata dampak epilepsi 57,11 $\pm 24,50$; ingatan dan konsentrasi 53,54 \pm 26,66; kemampuan fisik 65,56 \pm 23,67; stigma masyarakat 52,23 \pm 17,48; dukungan

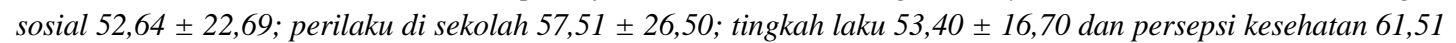
$\pm 11,30$. Analisis regresi linear ganda menunjukkan kualitas hidup tidak berhubungan secara bermakna dengan dengan lama menderita epilepsi, jenis kelamin dan status gizi ( $p>0,05)$, tetapi semakin tinggi usia menurunkan kualitas hidup secara bermakna pada remaja $(p<0,05)$.

\section{KESIMPULAN}

Penderita epilepsi intraktabel remaja memiliki nilai yang lebih tinggi pada kemampuan fisik dan persepsi akan kesehatan namun lebih rendah pada stigma masyarakat. Dukungan sosial memiliki nilai yang sangat rendah. Semakin tinggi usia menurunkan kualitas hidup pada remaja dengan epilepsi intraktabel.

Kata kunci: Epilepsi intraktabel remaja, kualitas hidup

\section{INTRODUCTION}

Intractable epilepsy affects the life of the patient and society as a whole in a profound way. The patients suffer in terms of schooling and employment and are stigmatized. In addition, they frequently suffer from psychiatric complications, especially depression and anxiety. Mortality is increased secondary to seizure related accidents, higher suicide rates, and sudden unexpected death in epilepsy. Also, there is mounting evidence that uncontrolled seizures can lead to deterioration in cognition and developmental function. ${ }^{(1)}$ The goal of management and care of adolescents with epilepsy should enable them and their families to lead a life as free as possible from adverse medical and psychosocial complexities of epilepsy. ${ }^{(2)}$ Adolescents have different activities, levels of responsibility, different interests and areas of concern from those of younger adolescents and adults.

Pediatric epilepsy is a very complex neurological condition primarily characterized by the unexpected, episodic, and chronic nature of a variety of seizures, but also by different developmental, psychological, behavioral, 
educational, and social difficulties. As such, pediatric epilepsy has pervasive impacts on all aspects of a child's life. Health-related quality of life (HRQoL) is an important outcome in studies of pediatric patients with chronic physical illnesses such as asthma, diabetes or epilepsy. ${ }^{(3)}$

Several quality of life instruments for children with epilepsy are the questionnaire on quality of life for children with epilepsy (QOLCE); Brazillian quality of life questionnaire for children with epilepsy (QUCE); health related quality of life for childhood epilepsy (CHEQCH-25) and quality of life in epilepsy for adolescents (QOLIEAD-48). ${ }^{(4)}$

The quality of life in epilepsy for adolescents (QOLIE-AD-48) questionnaire is a health-related quality of life (HRQOL) instrument that has been developed to assess psychometric properties of specific areas for adolescents with epilepsy. ${ }^{(5)} \mathrm{A}$ study showed that duration of treatment was correlated with quality of life of adolescents with epilepsy. ${ }^{(6)}$ We aimed to determine the HRQOL in adolescents with intractable epilepsy and its correlated factors.

\section{METHODS}

\section{Research design}

This was a cross sectional study held in March 2014 in the Pediatric Neurology outpatient clinic of Dr.Soetomo Hospital, Surabaya.

\section{Research subjects}

We included adolescents with intractable epilepsy (partial or generalized), aged 10 to 16 years, who had their typical seizure recorded by electroencephalography (EEG). In this study, intractable epilepsy was defined according to the International League Against Epilepsy (ILAE) as seizures which occur despite the adequate administration of two tolerated, appropriately chosen and adequately used anti-epileptic drugs (AEDs). ${ }^{(4)}$ Subjects were excluded if they had a history of brain surgery, another psychiatric or progressive neurologic illness, and motoric deficits (spastic diplegia, spastic quadriplegia, hemiplegia, dyskinesia, ataxia and hypotonia). A total of 31 subjects were included in this study.

\section{Questionnaires}

All eligible subjects and their parents who agreed to participate in the study were interviewed to obtain demographic and personal information. Age was calculated from the birth date. Gender (sex) was assessed by physical examination. Nutritional status was based on the Center for Disease Control 2000 chart. Duration of epilepsy was determined from chronological age minus age at first diagnosis of epilepsy.

\section{Quality of life in epilepsy for adolescents}

The subjects were asked to complete a selfassessment of QOLIE-AD-48 with the assistance of an English interpreter. The QOLIE-AD-48 questionnaire contained 48 items in 8 subscales: epilepsy impact (12 items), memory-concentration (10 items), attitudes toward epilepsy (4 items), physical functioning (5 items), stigma (6 items), social support (4 items), school behavior (4 items), health perceptions (3 items), and total summary score. Total summary score was calculated and transformed linearly into scales of 1-100 points, using the scoring manual for QOLIE-AD-48. A higher value represents better functioning and wellbeing. Score 0 indicates very poor and score 100 indicates highest HRQOL. ${ }^{(3)}$ The health related quality of life scores are presented as mean and SD.

\section{Data analysis}

Descriptive statistics (means, SDs, ranges, minimum and maximum scores) were calculated using SPSS version 17.0 for each scale and for the summary score. Multiple linear regression test was used to analyze correlation between HRQOL and the variables duration of epilepsy, age, sex and nutritional status.

\section{Ethical clearance}

The ethical clearance certificate had been issued by the Committee of Human Health Research and Ethics of Dr. Soetomo Hospital. 


\section{RESULTS}

Thirty one patients with mean age of 12.41 \pm 1.40 years were enrolled, among whom twenty four $(77.5 \%)$ had moderate malnutriton. The mean duration of intractable epilepsy was $6.12 \pm 4.30$ years. Thirty subjects $(96.8 \%)$ used two antiepileptic drugs (AEDs) and one (3.2\%) used three AEDs. Among the adolescents who used two AEDs, valproic acid and phenytoin were prescribed for twenty two (70.9\%) subjects. The only subject (3.2\%) using three AEDS was prescribed valproic acid, carbamazepine and topiramate. Twenty four (77.4\%) adolescents attended public schools, and nine (37.5\%) of them had to repeat their school grades twice or more (Table 1).

Among the subscales of QOLIE-AD 48, the physical functioning scales of daily activities (such as walking to school, running, bicycle riding, carrying bags or taking a bath alone) was found to have a mean score of $65.48 \pm 23.68$. Stigmatization scales (considering themselves to be less happy, mentally unstable, rejected by opposite sex) had a mean score of 52.17 \pm 17.49 . One subject to whom was prescribed three AEDs had scores below the mean for all subscales, which consisted of epilepsy impact score 4.5, memory and concentration 7.5, physical functioning 25 , stigma 33.3, social support 100, school behavior 12.5, attitude toward epilepsy 25 and health perception score 33.3. Overall mean score of 8
Table 1. Distribution of characteristics of patients $(n=31)$

\begin{tabular}{|c|c|}
\hline Characteristics & $n(\%)$ \\
\hline \multicolumn{2}{|l|}{ Sex } \\
\hline B oys & $16(51.6)$ \\
\hline Gir1s & $15(49.4)$ \\
\hline Age (years) & $12.41 \pm 1.40$ \\
\hline \multicolumn{2}{|l|}{ Type of school } \\
\hline No schooling & $7(22.0)$ \\
\hline Public school & $24(77.4)$ \\
\hline \multicolumn{2}{|l|}{ Hist ory of repeating school grade } \\
\hline Once & $4(30.1$ \\
\hline Twice or more & $9(69.9)$ \\
\hline \multicolumn{2}{|l|}{ Parents education } \\
\hline E1 ementary school & $16(51.6)$ \\
\hline Junior high school & $10(32.3)$ \\
\hline Seni or high school & $4(12.9)$ \\
\hline B achelor & $1(3.2)$ \\
\hline \multicolumn{2}{|l|}{ Parents work } \\
\hline Unemployed & $6(19.4)$ \\
\hline Employed & $25(80.6)$ \\
\hline \multicolumn{2}{|l|}{ Fam ily incom e per month (IDR) } \\
\hline No income & $6(19.5)$ \\
\hline $500,000-750,000$ & $14(45.2)$ \\
\hline 750,000 or more & $11(35.3)$ \\
\hline \multicolumn{2}{|l|}{ Nutritional status } \\
\hline Well nourished & $7(22.0)$ \\
\hline Moder ately m alnourished & $\begin{array}{l}24(77.4) \\
6.12+430\end{array}$ \\
\hline Duration of epilepsy (years) & $6.12 \pm 4.30$ \\
\hline \multicolumn{2}{|l|}{ Number of AEDs } \\
\hline Two drugs & $30(96.8)$ \\
\hline Three dugs & $1(3.2)$ \\
\hline \multicolumn{2}{|l|}{ Type of AEDs } \\
\hline $\mathrm{V}$ alproic acid and phenantoin & $22(70.9)$ \\
\hline $\begin{array}{l}\text { V alproric acid and } \\
\text { carbamazepine }\end{array}$ & $8(25.8)$ \\
\hline $\begin{array}{l}\text { Valproic acid, topiram ate, and } \\
\text { carbamazepine }\end{array}$ & $1(3.3)$ \\
\hline
\end{tabular}

AEDs : Antiepileptic drugs

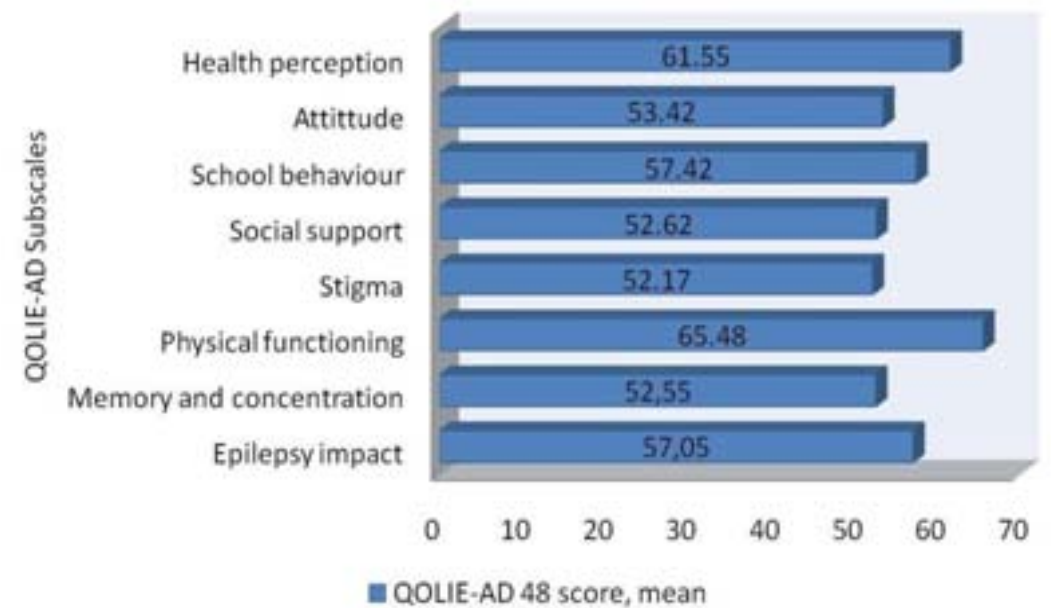

Figure 1. QOLIE-AD 48 scores for each subscale in adolescents with intractable epilepsy 
Table 2. Multiple linear regression of several variables with total mean score of HRQOL

\begin{tabular}{lcc}
\hline \multicolumn{1}{c}{ Variables } & $\boldsymbol{\beta}$ & $\mathbf{p}$ \\
\hline Duration of epilepsy & -0.06 & 0.75 \\
Sex & -1.33 & 0.47 \\
Age & -3.81 & 0.03 \\
Nutritional status & 0.02 & 0.99 \\
\hline$\beta=$ regression coeficient & &
\end{tabular}

subscales from 31 subjects was $51.86 \pm 19.32$. Figure 1 presents the scores of each subscale in adolescents with intractable epilepsy.

There was no correlation between HRQOL and duration of epilepsy, sex and nutritional status variables. There was a significant correlation between HRQOL and age of intractable epileptic adolescents. The subjects' quality of life decreased with increasing age $(\hat{a}=-3.81 ; p=0.03)($ Table 2$)$.

\section{DISCUSSION}

A full assessment of HRQOL issues in adolescents is complex because of the wide range of maturity within this age group, differences in independence and experience, and potential volatility of emotions. To consider adolescents as adults is problematic because of these developmental issues. ${ }^{(5)}$ Our study recruited 31 adolescents with intractable epilepsy according to the inclusion criteria, aged 10-16 years, with equal sex distribution. The mean duration of epilepsy was $6.12 \pm 4.30$ years. Overall mean score of 8 subscales from 31 subjects was 51.86 \pm 19.32. Sabaz et al. ${ }^{(8)}$ used the Child Behaviour Checklist (CBCL) on adolescents with refractory epilepsy and found that intellectually normal adolescents with refractory epilepsy were more likely to have emotional, behavioral, and cognitive problems and to be less competent in socializing and school performance. The total problem score was $48.82 \pm 11.12$ in adolescents with refractory epilepsy without seizures during the past 4 weeks and 54.01 \pm 11.17 in adolescents with refractory epilepsy with seizure fequency of more than 10 seizures per month. The correlation between seizure frequency and total problem score was significant $(\mathrm{p}<0.01) .{ }^{(8)}$ Sabaz et al. ${ }^{(8)}$ mentioned as the limitations of previous studies using CBCL the diagnostic criteria in the classification of epilepsy syndrome, the evaluation of epilepsy severity, and the fact that they did not accurately established the cognitive normality of the subjects.

Cramer et al. ${ }^{(5)}$ used the same QOLIE-AD 48 instrument as in our study, and found a higher overall mean score. In epileptic adolescents without seizure, the overall mean score was 77.3 (SD 12.6) and in epileptic adolescents with high severity seizure, the overall mean score was 62.7 (SD 16.5). The different results were due to the dissimilarity of the inclusion criteria. Cramer et al. ${ }^{(5)}$ included all adolescents with epilepsy, including those who were not intractable and used AED monotherapy. Furthermore, the types of epilepsy were not mentioned in their inclusion criteria for the study. Monir et al. ${ }^{(9)}$ stated that a lower mean score of all domains of quality of life was correlated with generalized epilepsy, frequent episodes of seizure, use of AED polytherapy, younger age of seizure onset, and longer duration of illness.

In our study, valproic acid and phenytoin were prescribed for most of the subjects, while phenytoin and carbamazepine were used in eight subjects. Modi et al. ${ }^{(10)}$ described that adolescents to whom carbamazepine monotherapy was prescribed had declining emotional functioning in seven months of follow up, compared with those to whom valproic acid was prescribed, who demonstrated steady or improving emotional functioning regardless of initial side-effect severity. Eddy et al. ${ }^{(11)}$ stated that phenytoin has been implicated in decline in consentration, memory, visuomotor functions and mental speed. However, the decline in attention and motor performance were said to be improved after withdrawal of therapy. A randomized, doubleblinded, placebo-controlled study involving 150 epilepsy subjects on AED monotherapy (mainly carbamazepine or valproic acid) found that drug discontinuation significantly improved performance requiring complex cognitive processing. ${ }^{(12)}$ These previous studies were not 
designed to evaluate overall HRQOL, but only the emotional, attention and cognitive aspects, related to type and side effects of the AEDs prescribed to the subjects. The type of epilepsy and the frequency of seizures were not mentioned. Nevertheless, a routine assessment of AED side effects whenever used as a polytherapy and its implication on HRQOL may be useful for further longitudinal, prospective studies in adolescents with intractable epilepsy.

Stigmatization scales (considering themselves to be less happy, mentally unstable, rejected by opposite sex) had a mean score of $52.17 \pm 17.49$. Social support scales had a mean score of 52.62 \pm 22.70 .

Aydemir et al. ${ }^{(13)}$ conducted a study on 70 subjects with epilepsy and noted that the impact of stigma in epileptic subjects was greater and extended beyond the neurological condition itself, and lowered the overall HRQOL score. Siqueira et al. ${ }^{(14)}$ stated that a high prevalence of social support and knowledge about epilepsy may influence the way adolescents relate to the disease and thus provide a better adaptation to and acceptance of the limits imposed by epilepsy. Both values will promote a valuable way to adaptation, acceptance, increased self-esteem, overcoming of stigma, resulting in a higher HRQOL. In our study, stigma and social support were two of the lowest scales found. Parents and close family were the only main source of social support for our subjects. Limited parental education and family income may contribute to poor overall HRQOL scales. Level of knowledge about epilepsy and its impact were not assessed in this study. Better social support, apart from that of the family, is needed in order to obtain higher self esteem and HRQOL scores.

In our study there was no correlation between duration of epilepsy and HRQOL. A similar study using QOLIE-AD 48 conducted by Taylor et al. ${ }^{(15)}$ found that adolescents with new-onset epilepsy (less than 3 years of onset), particularly those with comorbid conditions, are at risk of reduced QOL at the time of diagnosis. It is stated furthermore that psychosocial problems are the comorbid conditions that could lower QOL scores and need to be assessed earlier to improve the QOL scores. ${ }^{(15)}$ Shakir and Al-Asadi stated that the association between duration of epilepsy (less than 5 years of onset versus more than 5 years) and QOL was not significant. A possible explanation might be related to age as a potential confounder. A specific age sampling of epileptic patients is needed in further studies. ${ }^{(16)}$ Another study also stated that the correlation between duration of illness and QOL was not significant. However, the duration of illness was significantly correlated with caregiver rating of the patient as having higher QOL. ${ }^{17)}$

The correlation of HRQOL and age was significant in the present study. Few previous studies noted that there was a fair correlation between epilepsy impact and memory or concentration, and that HRQOL was significantly associated with age. Our overall scores of QOLIEAD-48 show that adolescents with epilepsy have moderate levels of QOL. ${ }^{(18-20)}$ The other nonsignificant correlation in this study was with the variable of sex. Similar results were found in a few prior studies. ${ }^{(21,22)}$ Other factors that correlated with HRQOL and needed to be approached in order to achieve a higher HRQOL were psychosocial consultation, family support programs and health education for parents, teachers and the public about different aspects of epilepsy. ${ }^{(23)}$ Seizure control and early behavioral problem identification also play a role in obtaining better HRQOL scores. ${ }^{(24)}$ The results of this study reflect the HRQOL of a limited population of adolescents due to the relatively small and homogeneous study sample. The cross-sectional design of the study precluded conclusions about the direction of association between predictors and HRQOL variables.

Further studies with greater numbers of subjects and longer periods of follow up are needed to better assess the risk factors for higher HRQOL in adolescents with intractable epilepsy. A routine HRQOL assessment may be useful in daily practice, especially in intractable epilepsy patients who need AED polytherapy. 


\section{CONCLUSIONS}

Intractable epileptic adolescents in the Pediatric Neurology outpatient clinic of Dr. Soetomo Hospital had higher scores for physical functioning and health perception, but lower scores for stigmatization of epilepsy. Social support had the lowest score. Increasing age was significantly decreases quality of life in adolecents with intractable epileptic.

\section{CONFLICT OF INTERESTS}

The authors declare to have no conflict of interest.

\section{ACKNOWLEDGEMENT}

The authors would like to thank Ms Mahmudah for her enthusiasm in supporting us with statistical analysis.

\section{REFERENCES}

1. Sinha S, Siddiqui KA. Definition of intractable epilepsy. Neurosciences 2011;16:3-6.

2. Lach LM, Ronen GM, Rosenbaum PL, et al. Health-related quality of life in youth with epilepsy: theoretical model for clinicians and researchers. Part I: The role of epilepsy and comorbidity. Qual Life Res 2006;15:1161-71.

3. Zashikhina A, Hagglof B. Health-related quality of life in adolescents with chronic physical illness in northern Russia: a cross-sectional study. Health Qual Life Outcomes 2014;12:12.

4. Waters E, Davis E, Ronen GM, et al. Quality of life instruments for children and adolescents with neurodisabilities: how to choose the appropriate instrument. Dev Med Child Neurol 2009;51:6609. DOI: 10.1111/j.1469-8749.2009.03324.x.

5. Cramer J, Westbrook LE, Perrine K, et al. Development of the quality of life in epilepsy inventory for adolescents: the QOLIE-AD-48. Epilepsia 1999;40:1114-21.

6. Malhi P, Singhi P. Correlates of quality of life with epilepsy. Indian J Pediatr 2005;72:131-5.

7. Kwan P, Arzimanoglou A, Berg AT, et al. Definition of drug resistant epilepsy: consensus proposal by the ad hoc task force of the ILAE commission on therapeutic strategies. Epilepsia 2010;51:1069-77.
8. Sabaz M, Cairns DR, Lawson JA, et al. The health-related quality of life of children with refractory epilepsy: a comparison of those with and without intellectual disability. Epilepsia 2001;42:621-8.

9. Monir ZM, El-Alameey IR, Eltahlawy E. Health related quality of life of children with epilepsy in Egypt. J Arab Soc Med Res 2013;8:53-66.

10. Modi AC, Ingerski LM, Rausch JR, et al. Treatment factors affecting longitudinal quality of life in new onset pediatric epilepsy. J Pediatr Psychol 2011;36:466-75.

11. Eddy CM, Rickards HE, Cavanna AE. The cognitive impact of antiepileptic drugs. Ther Adv Neurol Disard 2011;4:385-407.

12. Hessen E, Lossius MI, Reinvang I, et al. Influence of major antiepileptic drugs on attention, reaction time and speed of information processing: result from a randomized, doubleblind, placebo-controlled withdrawal study of seizure-free epilepsy patients receiving monotherapy. Epilepsia 2006;47:2038-45.

13. Aydemir N, Ozkara C, Unsal P. A comparative study of health related quality of life, psychological well-being, impact of illness and stigma in epilepsy and migraine. Seizure 2011; 20:679-85.

14. Siqueira NF, Guerreiro MM, Pedroso de Souza EA. Self-esteem, social support perception and seizure controllability perception in adolescents with epilepsy. Arq Neuropsiquiatr 2011;69:7704.

15. Taylor J, Jacoby A, Baker GA, et al. Self-reported and parent-reported quality of life of children and adolescents with new-onset epilepsy. Epilepsia 2011;52:1498-98.

16. Shakir M, Al-Asadi J. Quality of life and its determinants in people with epilepsy in Basrah, Iraq. SQU Medical Journal 2012;12:449-57.

17. Ohaeri JU, Awadalla AW, Farah AA. Quality of life in people with epilepsy and their family caregivers: An Arab experience using the short version of WHO Quality of Life Instrument. Sustech 2009;30:1-22.

18. Kerr C, Nixon A, Angalakuditi M. The impact of epilepsy on children and adult patients' lives: development of a conceptual model from qualitative literature. Seizure 2011;20:764-74.

19. Sharoni SK, Rahman JA, Jamaludin MA, Radzi NM. HRQOL among children with epilepsy. International J Undergraduates Study 2013;2:1925.

20. Aggarwal A, Datta V, Thakur LC. Quality of life in children with epilepsy. Indian Pediatrics 2011; 48:893-6. 
21. Norsa'adah B, Zainab J, Knight A. The quality of life of people with epilepsy at a tertiary referral centre in Malaysia. Health Qual Life Outcomes 2013;11:1-6.

22. Karakis I, Cole AJ, Luciano MS, Meador KJ, Piperidous C. Caregiver burden in epilepsy: determinants and impact. Epilepsy Res Treat 2014;1:1-9.
23. Abbas Z, Elseed MA, Mohammed IN. The quality of life among Sudanese children with epilepsy and their care givers. Sudanese J Pediatr 2014;14:51-8.

24. Kanemura H, Aihara M. Behavioural consequences in children with epilepsy. J Child Adolesc Behav 2013;1:1. 